University of Michigan Law School

University of Michigan Law School Scholarship Repository

Articles

Faculty Scholarship

1908

\title{
Labor Organizations in Legislation
}

Jerome C. Knowlton

University of Michigan Law School

Available at: https://repository.law.umich.edu/articles/1519

Follow this and additional works at: https://repository.law.umich.edu/articles

Part of the Constitutional Law Commons, Courts Commons, Labor and Employment Law Commons, Legislation Commons, and the Supreme Court of the United States Commons

\section{Recommended Citation}

Knowlton, Jerome C. "Labor Organizations in Legislation." Mich. L. Rev. 6, no. 8 (1908): 609-23.

This Article is brought to you for free and open access by the Faculty Scholarship at University of Michigan Law School Scholarship Repository. It has been accepted for inclusion in Articles by an authorized administrator of University of Michigan Law School Scholarship Repository. For more information, please contact mlaw.repository@umich.edu. 


\section{MICHIGAN}

\section{LAW REVIEW}

VOI. VI

JUNE, I908

No. 8

\section{LABOR ORGANIZATIONS IN LEGISLATION}

$\mathrm{D}^{\mathrm{U}}$

URING the first months of the current year, the Supreme Court of the United States handed down three decisions on important questions in labor legislation.' The Employers' Liability Act was declared unconstitutional, but on grounds that may be avoided by subsequent legislation; the boycott was decided to be an unlawful conspiracy against interstate commerce, and in violation of the AntiTrust Act and the congressional enactment providing criminal punishment for the discharge of an employee because of his membership in a labor organization was also held unconstitutional. These decisions have been unjustly spoken of by some, as unreasonably severe on labor organizations. The benefits that have come to laborers through the labor unions are recognized by the Court, but it is also pointed out that they can not secure their ends, however desirable they may be, through unlawful means and cannot abridge the constitutional personal rights of others through state or national legislation:

The case of Loezve v. Lazelor, known as the Hatter's Case, in which ChIFF JUSTICE FULLER delivered the opinion of the court, is perhaps the most important on the general subject. The decision has been most bitterly criticized by persons of prominence in labor organizations.

This was an action brought under Section 7 of the Anti-Trust Act of July 2nd, I890, claiming three-fold damages for injuries inflicted on the plaintiff by a combination or conspiracy declared to be unlawful by the act. The opinion sets out the complaint in full. It is a remarkable document in pleading, covering some 7000 words.

\footnotetext{
1 Howard v. Illinois Central Railway, decided January 6, 1908, 207 U. S. 463, 28 Sup. Ct. Rep. 141; Adair v. United States, decided January 26, 1908, 208 U. S. 161, 28 Sup. Ct. Rep. 277 ; Loewe v. Lawlor, decided February 3, 1908, 208 U. S. 274, 28 Sup. Ct. Rep. 301 .
} 
The wrong complained of is, in brief, that the defendants combined collectively with the United Hatters of North America, acting under The American Federation of Labor, of which the defendants were members, to ruin plaintiffs' interstate business, by means of a boycott against hats made at Danbury, Connecticut, and sold by plaintiffs throughout the United States. The boycott was declared against plaintiffs to compel them to unionize their factory. The complaint was demurred to and District JUDGE PLATrY for the District of Connecticut sustained the demurrer. It was conceded that the complaint showed that by means of the boycott the defendants sought to curtail and, if possible, to destroy, plaintiffs' production of hats at home and the distribution of such product after it had become settled into the stock of goods in the hands of the plaintiffs' customers in other states. In sustaining the demurrer the District Judge gave as his reason: "There is no allegation which suggests that the means of transporting plaintiffs' product or the product itself while being transported were touched, handled, obstructed, or in any manner actually interfered with. There is no allegation that the defendants are in any way engaged in interstate commerce."

The Supreme Court of the United States reversed the judgment of the lower court, holding that the boycott of plaintiffs' business was a common law wrong, in that: "At common law every person has individually, and the public also have collectively, a right to require that the course of trade should be kept free from unreasonable obstruction;"3 and that the facts set forth in the complaint brought the case clearly under Section $I$ of the Anti-Trust Law, declaring: "Every contract, combination in the form of trust or otherwise, or conspiracy, in restraint of trade or commerce among the several states, or with foreign nations, is hereby declared to be illegal."

This decision holds, in effect, that the federation of labor is a trust or an otherwise combination and that it cannot interfere with freedom of commerce between the states by means of a boycott. without rendering its officers and members who act for it, to that end, liable in treble damages to the party injured. It will be noticed that the same statute provides a punishment by fine and imprisonment fo: any person, who shall engage in any such combination or conspiracy. This leaves the boycott without much efficiency. It cannot be used against manufacturers of articles of interstate commerce, and is equally within the spirit and letter of state anti-trust

2148 Fed. R. 921.

Shief Justice Earl on Trade Unions, cited by Chief Justice Fuller. 
legislation, in matters of domestic commerce. The decision is based on principles announced in previous decisions of the court, ${ }^{4}$ with special reference to Srerift v. United States, ${ }^{5}$ Aikens v. Wisconsin, ${ }^{\circ}$ Addyston Pipe and Stecl Co. v. United States, and Montague and Co. v. Lowry. ${ }^{\top}$

These cases involved illegal combinations of capital, but the court held that combinations of laborers in restraint of interstate trade were as much under the condemnation of the statute as combinations of manufacturers or tradesmen. The Court refers with approval to the Debbs Case, also to the decision of District Judge Billings in the case involving the New Orleans strike of 1892 , in which it was held that a combination of laborers to effect a discontinuance of labor in all departments of business, including transportation of goods from state to state, was a combination in restraint of interstate commerce, and the fact that the restraint affected state commerce as well did not render the acts lawful or any the less against interstate trade. The supreme court did not regard the objections to the complaint sustained by the lower court as tenable, and held that there was set forth an illegal combination in restraint of interstate commerce, even though it appeared, "That the restraint alleged would operate to entirely destroy defendants' business and thereby included intrastate trade as well; that physical obstruction is not alleged as contemplated; and that defendants are not themselves engaged in interstate trade." The fact that the several acts complained of were of themselves innocent acts was relied upon as a defense, but the court quoted in answer to this from the opinion of JUSTICE Holmes in the Aikens Case (supra). "Every plot is an act in itself. $* * *$ The most innocently and constitutionally protected of acts or omissions may be made a step in a criminal plot, and, if it is a step in that plot, neither its innocence nor its constitutionality is sufficient to prevent a punishment of the plot by law."

The boycott and the "sympathetic strike" have for years been most effective in securing favorable action on the demands of organized labor. The decision of the court in the Hatter's case is clearly to the effect that both these agencies work a common law wrong and where they. interfere with interstate commerce are, as generally conducted, in violation of the Anti-Trust Act. Upon this question

\footnotetext{
- United States v. Trans-Missouri Freight Asso., 166 U. S. 290; United States v. Joint Traffic Asso., 171 U. S. 505; Northern Securities Co. v. United States, 193 U. S. 197.

196 U. S. 395

- 195 U. S. 194

7 Addyston Pipe \& Steel Co. v. United States 175 T S. 217; Montague \& Co. v. Lowry, 193 U. S. 38.

8158 U. S. 564 .
} 
there is some conflict in the decisions of the state courts, settled by the decision in this case so far as this question is involved.

It is now proposed to amend the act, by excepting from its operation combinations of farmers and laborers. Such an amendment would give rise to some serious constitutional questions. Congress may by such an exception deprive persons of the specific remedies called for in the act, but that would not deprive courts of law and equity of the power to grant relief as against a tortious act inflicting damage upon a person's property-right in interstate trade. Moreover, can Congress legalize a combination of capitalists, farmers or laborers to the extent of giving them the power of practically prohibiting commerce between the states, through the boycott or any other agency? Congress is given the power to regulate, but not the power to prohibit, the lawful interchange of articles of commerce between the several states. Such an exception to the act is suggested without due consideration of the judicial power of the courts under the constitution and the intent and meaning of the commerce clause and the property-rights clauses of the same instrument. To this decision of the court no dissenting opinion seems to have been handed down.

The case of Williom Adair v. United States, decided the same term, gave the court more trouble.

William Adair, a master mechanic and employer of the Louisville and Nashville Railroad Company, common carrier of interstate commerce, discharged from the employ of the company one Coppage by reason of his membership in a labor organization, known as the Order of Locomotive Firemen. Adair was indicted in the District Court of the United States for the eastern district of Kentucky and charged with having unjustly discriminated against Coppage, an employee of a common carrier engaged in interstate commerce, by reason of his membership in a labor organization; in violation of Section ro of the Act of Congress of June I, I898, "concerning carriers engaged in interstate commerce and their employees." This section makes it a crime to unjustly discriminate against any employee of an interstate carrier, because of his being a member of a labor organization. Defendant Adair demurred to the indictment. The facts charged in the indictment brought the case clearly within the terms of the statute and the questions on the demurrer involved the constitutional power of Congress to punish criminally an employer engaged in interstate commerce, for discharging an employee in violation of this section, when the contract of employment was for an indefinite period and terminable at any time at the will of 
either party. District Judge Cochran held that Section ro of this act was constitutional; that it did not violate the $5^{\text {th }}$ Amendment of the Federal Constitution, providing that no person shall be deprived of life, liberty or property without due process of law: that it was a reasonable regulation under the interstate commerce clause, subject to which liberty of contract was guaranteed; that while a contract of service between an employer engaged in interstate commerce and his employee was not strictly within the letter of interstate commerce it was an adjunct or incident of such commerce and therefore a proper subject of congressional regulation; and further, that while the act might be objectionable, on grounds of policy as class legislation, yet there was no provision in the constitution prohibiting Congress from passing laws subject to such objection, that the provision against class legislation applied only to state action. The demurrer was overruled and defendant was convicted, and the case was brought for review before the supreme court of the United States.

Mr. Justice HarLan writing for the Court held that Section Io of this act was void for the reason that it deprived the defendant of his liberty of contract guaranteed by the 5 th Amendment of the United States Constitution. Justices MCKENNA and Holares dissented.

The act of 1898 was an outgrowth of the Chicago strike of 1894 and the general purpose of the act was to provide for the voluntary arbitration of labor disputes between carriers and employees engaged in interstate commerce. In this way it was thought that the dangers to interstate commerce arising from strikes, boycotts and lockouts might be avoided. When the bill was up for consideration before the senate the committee on education in its report said of the bill, "The necessity for the bill arises from the calamitous results in the way of ill-considered strikes arising from the tyranny of capital or the unjust demands of labor organizations, whereby the business of the country is brought to a standstill and thousands of employees with their helpless wives and children are confronted with starvation." Section Io was included in the act on the theory that it would be helpful to its general purpose, but just how is not quite clear. This much is certain, it gave to "union" men protection not accorded to "non-union" men and was in that respect a piece of class legislation not generally regarded with favor. In his opinion Mr. Justrice HaRLAN says: "It may be observed in passing that while this section makes it a crime against the United States to unjustly discriminate against an employee of an interstate carrier be- 
cause of his being a member of a labor organization, it does not make it a crime to unjustly discriminate against an employee of a carrier because of his not being a member of such an organization."

Before the passage of this act the substance of section Io had been incorporated in the statutes of several states, providing for criminal punishment of an employer who discharged an employee by reason of his membership in any labor organization, or who exacted as a condition of employment that the employee should not become a member of any labor union. The state courts have quite uniformly held such statutes to be unconstitutional in that they violated both the federal and state constitutional guarantees of personal liberty and private property.

In State v. Ketzenberger, ${ }^{10}$ the defendant had been arrested upon a complaint charging him with having unlawfully discharged an employee because said employee was a member of a labor organization. The complaint and warrant were under a fairly typical statute. $^{\text {ix }}$

The case came before the supreme court of Wisconsin on a return to a writ of habeas corpus sued out by the defendant. The court held, in a very exhaustive opinion, by DoDge J., that the law was not a valid exercise of police power but an unwarranted interference with freedom in making contracts and an infringement of the right to "liberty and the pursuit of happiness" guaranteed by state and federal constitutions. The decision is based on the fundamental doctrine that, "It is a part of every man's civil rights that he be left at liberty to refuse business relations with any person whomsoever whether the refusal rests upon reason, or, as the result of whim, caprice, prejudice, or malice."12 Limitations on this right to the police power of the state are distinctly pointed out. but it is held that the statute is not a proper exercise of the police power for the reason that "It does not in terms or by implication promote, or pretend to promote the public health, welfare, confort or safety."

In People v. Marcus, ${ }^{13}$ the defendant was convicted of violating a similar statute. He had required as a condition of employment that the employee sign a written agreement containing this clause:

"State v. Katzenberger, 114 Wis. 530; State v. Julow, 129 Mo. 163; Gillespie v. People 188 Ill. $176 ;$ People v. Marcus, 185 N. Y. 257.

"The Wisconsin statute of 1899 provided that, "No person. corporation, agent or officer on behalf of any person or corporation, sliall force or compel any person or persons into an agreement either written or verbal, not to join or become a member of any labor organization, as a condition of such person or persons securing employment, or continuing in the employment of any such person or corportion, and no person or corporation shall discharge an employee because he is a member of any labor organization." A heavy fine was imposed for violation of this statute.

12 Cooley's Torts, p. 278.

13185 N. Y. 257. 
"Party of the second part hereby agrees not to belong to any labor unions or to take part in any strike against the party of the first part and to work as an individual in the open shop of party of the first part." This act was in open violation of the statute, but the New York Court of Appeals set the conviction aside for the reason that the law was unconstitutional. The court said in its conclusion that, "the freedom of contract which entitles an employer to make by agreement his place of business wholly within the control of a labor union (Jacobs v. Cohen, 183 N. Y. 207), entitles him, if he so desires, to require of his employees that they be wholly indepenclent of any labor union;" and that, "he cannot be deprived of this right by legislation."

In the Adair Case, District Judge Cochran called attention to these decisions of the state courts, but held that they did not apply to the case before him for that, in those cases, the legislation in question was being enforced against persons engaged in private business and not against persons engaged in interstate commerce or in the employ of public service corporations. This distinction is regarded as controling by JUSTICE MCKENNA. In his dissenting opinion in the Adair Case, he says: "I would not be misunderstood. I grant that there are rights which can have no material measure. There are rights which, when exercised in a private business, may not be disturbed or limited. With them we are not concerned, we are dealing with rights exercised in a quasi-public business and therefore, subject to control in the interest of the public."

After reviewing recent decisions of the court on liberty of contract, JUSTICE, HARLAN wrote, on the main question before the court: "It was the legal right of the defendant Adair-however unwise such a course might have been-to discharge Coppage because of his being a member of a labor organization, it was the legal right of Coppage, if he saw fit to do so,-however unwise such a course on his part might have been-to quit the service in which he was engaged, because the defendant employed some persons who are not members of a labor organization. In all such particulars the employer and employee have equality of rights, and any legislation that disturbs that equality is an arbitrary interference with liberty of contract which no government can legally justify in a free land." The opinion is based largely on the principles announced in Lochner v. New York. ${ }^{14}$ When the decision in the Lochner Case was handed down it was regarded as one of great significance, greater perhaps than that of any case for many

14198 U. S. $45,53,56$.

15 People v. Lochner, 177 N. Y. 145. 
years past. The court of last resort in New York ${ }^{15}$ had, by a divided court, sustained the constitutionality of a statute prohibiting contracts for more than ten hours labor per day in a bakery, and the Supreme Court of the United States by a divided court reversed the decision on the ground that the statute was in violation of the I4th amendment to the United States Constitution. Some learned writers on constitutional questions criticized this decision, as not being in harmony with the previous decisions of the Supreme Court, particularly the case of Holden. v. Hardy, wherein it was said: "the constitution of the United States $* * *$ should not be so construed as to deprive the states of their power to amend their laws so as to make them conform to the wishes of the citizens as they may deem best for the public welfare without bringing them into conflict with the supreme law of the land."16 It was contended by some that the Lochner decision placed matters of purely domestic concern, heretofore supposed to be under state control, under supervision of the federal judiciary. Prof. Freund in commenting on it wrote: "A decision which reads into the $\mathrm{r} 4^{\text {th }}$ amendment a vague and controverted conception of the liberty of contract is a novel and hardly a fortunate step in the development of our constitutional law."17 Others looked upon the decision in the Lochner Case much more favorably and regarded it as giving to the I4th Amendment a construction of pronounced value to the individual; that under it he was guaranteed against any unreasonable restraint or abridgement of his personal and property contract rights by the action of state legislatures, induced by the vote-getting power of voluntary organizations of labor or capital. The writer's personal views of this decision have heretofore been expressed. ${ }^{18}$ It was feared, however, that a decision by a court, so evenly divided, might not stand long and might soon go the way of other "cases distin-. guished." The Adair Case removes all apprehension, and it is worthy of note that the prevailing opinion in this case is written by Mr. Justice HaRLAN who wrote the leading dissenting opinion in the Lochner Case. He points out that in the latter case, the difference of opinion among the members of the court arose over the question as to whether labor in a bakery is so unhealthful as to call for limitation on the hours of labor therein through the police regulation, and as to whether in cases of doubt the determination should be left to the individual states. Upon the fundamental question JUSTICE HARLAN referring to the Lochner Case wrote:

${ }^{26}$ Holden v. Hardy, 169 U. S. 366.

17 The Green Bag Vol. 17 p. $4: 14$

183 Mich. Law Rev. 617. 
"Although there was a difference of opinion in that case among the members of the court as to certain propositions, there was no disagreement as to the general proposition that there was a liberty of contract which cannot be unreasonably interfered with by legislation."

The most serious question before the Court in the Adair Case arose out of a difference of opinion among the members of the court as to whether the statute in question could be regarded in any sense as a regulation of interstate commerce. JuSTrCES MCKENNA and HoLMES in their dissenting opinions, reached the affirmative of that proposition on the ground that the power of regulation extended to the persons engaged in interstate commerce and that the statute in question is a proper exercise of that power. Many decisions are referred to in support of this view, following Gibbons v. Ogden, ${ }^{19}$ in which Mr. JUSTICE JoHnson said, "Commerce in its simplest signification, means an exchange of goods, but in the advancement of society, labor, transportation, intelligence, care and various means of exchange become commodities and enter into commerce; the subject, the vehicle, the agent and their various operations become the object of commercial regulations."

An examination of those cases discloses, however, that the decisions referred to involved simply the supreme federal power in police regulation over matters subject to congressional action under the constitution and did not in any sense involve contractual rights of the individual. The Northern Securities Case ${ }^{20}$ and Joint Traffic Association Case $^{21}$ relied on in the dissenting opinions involved proceedings against corporations to have them declared illegal combinations in violation of the Anti-Trust Act.

Without recognizing the bearing of those cases on the question in the Adair Case, Mr. Justice HarLan, speaking for the court, objects to the legislation under consideration on the ground that it has no proper relation to interstate commerce. He wrote: "Manifestly, any rule prescribed for the conduct of interstate commerce, in order to be within the competency of Congress, under its power to regulate commerce among the states, must have some real or substantial relation to or connection with commerce regulation. But what possible legal or logical connection is there between an employee's membership in a labor organization and a carrying on of interstate commerce? That relation to a labor organization cannot have, in

109 Wheat. 1.

20193 U. S. 200

21171 U. S. 571 . 
itself and in the eye of the law, any bearing upon the commerce with which the employee is connected by his labor and service."

This is the precise question and the only one involved of practical value. Can labor organizations through the sanction of state or federal legislation deprive the individual of liberty of contract on the ground that labor unions are so conducive to the public welfare that the police power of the state may be exercised in their promotion at the expense of individual freedom. The dissenting opinion of JUSTICE Holmes inclines to the affirmative of this question. $\mathrm{He}$ writes, speaking of Section Io of this statute: "But suppose the only effect really were to tend to bring about complete unionizing of such railroad laborers as Congress can deal with, I think that object alone would justify the act. I quite agree that the question what and how much good the labor unions do, is one on which intelligent people may differ,-I think that laboring men sometimes attribute to them advantages, as many attribute to combinations of capital disadvantages that really are due to economic conditions of a far wider and deeper kind,- - but I could not pronounce it unwarranted if Congress should decide that to foster such unions was for the best interest, not only of the men, but of the railroads and the country at large."

This is not a new but is a somewhat alarming doctrine. The state and national constitutional guarantees ought to rest, through judicial construction, on a firmer and more definite basis than any legislative notion as to the right of conflicting industrial economic theories.

Conceding, if one cares to, that the legislation in question has sufficiently direct relation to interstate commerce, this does not amount to a concession of its constitutionality. The commerce clause and the personal rights clause of the constitution must be construed together. One is a grant of power and the other is a limitation on the power of Congress. The grant should not be so liberally extended as to impair unnecessarily the limitation. "The power to regulate commerce has no limitations other than those prescribed in the constitution. Power, however, does not carry with it the right to destroy or impair those limitations and guarantees which are also placed in the constitution or in any of the amendments to that instrument. Monongahela Navigation Company v. United States, 148 U. S. 312 ; Interstate Commerce Commission v. Brimson, I54 U. S. 447." One of the limitations and guarantees included in that instrument is the guarantee of liberty of contract. This is, of course,

$=171$ U. S. 571 . 
subject to the police power of regulation for the protection of the public health, public safety, or public service, but what relation is there between any one of these and membership in a labor organization? JUSTICE MCKENNA, writing in dissent, calls attention to the fact that the action in question was passed in hope that it would reduce to the minimum labor strikes which affect interstate commerce, he speaks of it as, "A provision of law which shall prevent or tend to prevent the stoppage of every wheel in every car in an entire railroad system engaged in interstate commerce." Ought the government to yield to the demands of any class of persons through fear that, unless its demands are complied with, it will through illegal or violent measures impair freedom of commerce? Must the government consent to the unionizing of labor, at the expense of constitutional guarantees, in order that public safety may be conserved from violence and disorder? Upon this view of the subject JUSTICE HARLAN wrote: "Will it be said that the provision in question had its origin in the apprehension, on the part of Congress, that if it did not show more consideration for members of labor organizations that for all of them or any who were not members of such organizations, or if it did not insert in the statute some such provision here in question, members of labor organizations would, by illegal or violent measures, interrupt or impair freedom of commerce among the states? We will not indulge in any such conjectures, nor make them, in whole or in part, the basis of our decision. We cannot do so consistently with the respect due to a coordinate department of the government."

The action of Congress in relation to car couplers on cars used in interstate commerce, ${ }^{23}$ in relation to pilots engaged in marine navigation, etc. ${ }^{24}$ and the action of state legislatures in relation to the qualifications of engineers of locomotives through their technical knowledge, ${ }^{25}$ or their disqualification through physical infirmity, such as color blindness, ${ }^{26}$ all to be determined by bodies provided for under competent authority, have been sustained as a proper exercise of the police power of the state and for the public safety, but what relation is there between the public safety and membership in a labor union? None whatever, unless we can say that the union, a voluntary organization, not even a legal entity, and without personal responsibility to the government, will resort to violent measures dangerous to life and property and must therefore be recog-

3 Johnson v. Railroad 196 U. S. 1

z Cooley $v$ Board of Wardens 12 How. 299.

$\approx$ Smith v. Alabama 124 U. S. 465.

26 Nashville Railway v. Alabama, 128 U. S. 96. 
nized and conciliated. Such a concession to any voluntary organization of labor or capital would be dangerous. Fear of violence and disobedience to law should not be recognized. Violence is an evil to be avoided and overcome, but not to be feared by the law-making power, and the individual personal right of contract ought not to be sacrificed in a compromise between lawlessness and governmental power.

Danger of violence and interruption of intrastate commerce through strikes of labor organizations are as pressing and of more frequent occurrence than in interstate commerce, but the state courts, as the cases referred to show, have quite uniformly held that these dangers do not justify interference with the personal liberty of contract by state legislation. Has Congress a greater power of control in matters of interstate commerce than has the state over matters of intrastate commerce? Cases may arise calling for an affirmative answer to these questions, but membership in a labor organization does not present such a case. The principle of limitation on state action expressed in the I4th Amendment and the limitation on federal action in relation to the same matter, expressed in the 5th Amendment to the Constitution of the United States should be construed in the same manner and given the same force and effect. The grant of power in Congress over interstate commerce should not be regarded as more extensive than the reserve power in the state over intrastate commerce. It is fortunate in the direction of settling of personal and property rights, that upon the main question, the federal and state courts are agreed, that legislation of the kind in question is unconstitutional.

The Supreme Court has left some questions arising out of the Adair Case undetermined. The District Judge held that, while the statute under consideration might be regarded as objectionable class legislation, yet that there is no constitutional objection to class legislation by Congress and therefore the statute could not be regarded as unconstitutional on that ground. For obvious reasons the final determination of the case rendered unnecessary any consideration of this question; but the pointed allusion in the prevailing opinion of the Supreme Court to the fact that the act discriminates between union and non-union men suggests a serious doubt as.to whether the court will ever hold that Congress has the power to make a person's full enjoyment of his constitutional guarantees dependent upon his becoming a member of any organization whatsoever. It should be remembered that these guarantees are not for classes but for the 
individual, and the right guaranteed to him cannot be impaired under the guise of class legislation.

In the opinion of the Court is this statement: "Without stopping to consider what would have been the right of the railroad company under the 5 th Amendment, had it been indicted under the act of Congress, it is sufficient in this case to say that, as agent of the railroad company and as such responsible for the conduct of the business of one of its departments, it was the defendant Adair's right-and that right inherent in his personal liberty, and so also a right of property-to serve his employer as best he could, so long as he did nothing that was reasonably prohibited by law as injurious to the public interest." This leaves open the question of constitutional objections to the statute as applied to the railroad company. If it be the right of the defendant Adair to prescribe the terms upon which the services of Coppage would be accepted are his rights greater than those of the company, his employer? Can a servant have greater rights in the performance of his master's business than the master? New conditions may call for new laws, but it is doubtful whether it will ever be safe to allow an employee greater freedom in the management of his employer's business than the employer himself has. That a quasi-public corporation has not the same rights under the constitution as a natural person has been long conceded. In the Northern. Securities Case," it was held that: "a corporation while by fiction of law recognized for some purposes as a person and for purposes of jurisdiction as a citizen, is not endowed with the inalienable rights of the natural person, but it is an artifcial person, created and existing only for the convenient transaction of business." The question, however, is, has not such a corporation the same personal and property rights of contract in the employment of its agents and employees as a private corporation or a natural-person?

The regulations which labor unions have adopted or may adopt for the government of their members and the conditions which confront the employer are set forth by DoDGe, $J$., in the Wisconsin Case (supra). "The success in life of the employer depends on the efficiency, fidelity and loyalty of his employees. Without enlarging upon or debating the relative advantages or disadvantages of the labor union, either to its members or to the community at large, it is axiomatic that an employer cannot have undivided fidelity, loyalty, and devotion to his interests from an employee who has given

${ }_{27} 193$ U. S. 200. 
to an association right to control his conduct. He may by its decisions be required to limit the amount of his daily product. He may be restrained from teaching his art to others. He may be forbidden to work in association with other men whose service the employer desires. He may not be at liberty to work with such machines or upon such materials or products as the employer deems essential to his success. In all these respects he may be disabled from the full degree of usefulness attributable to the same abilities in another who had not yielded up to an association any right to restrain his freedom of will and exertion. in his employer's behalf according to the latter's wishes. Such considerations the employer has a right to deem valid reasons for preferring not to jeopardize his success by employing members of organizations. A man who has by agreement or otherwise shackled ony of his faculties-even his freedom of will-may well be considered less useful or less desirable by some employers than if free and untramelled. Whether the workman can find in his membership in such organizations advantages and compensations to offset his lessened desirability in the industrial market is a question each must decide for himself."

Can Congress punish, through indictment, an interstate carrier, who declines to employ or refuses to retain in his employ a person who, by becoming a member-of a labor union, agrees to be bound by such or like regulations, while in his employer's business? If it can, then it must be because a public service corporation has, under the Constitution, very little of personal or property right of contract, guaranteed as against legislative violation.

It should be noted that the contract involved calls for services of a decidedly personal character requiring, in many cases, the utmost good faith on the part of both parties to the contract. Courts of law have long recognized this feature of personal service contracts and for that reason have sustained the right of either party to sever the contractual relation at will, giving only a remedy in damages, in case of breach of contract for a definite period, and courts of equity have uniformly declined to decree specific performance of such a contract. We are inclined to the view that the right to sever the relation, in a personal service contract, is a substantial right, which cannot be taken away by arbitrary legislation and the exercise of it cannot be made dependent on the fact that the contract does or does not call for a definite term of service. A decided disagreement for whatever cause between the employer and employee renders the continuance of the relation intolerable for both and, in public service corporations, such disagreement sometimes brings inconvenience 
and danger to the public. The right to terminate this personal relation is a substantial property right of which a public service corporation cannot be deprived except under the police power of the state and it is hoped that this extraordinary power will not be used to force the unionizing of labor and to crush out individualism on the theory that public safety demands such a concession; or on a supposed inability on the part of the government to suppress organized violence in behalf of labor or capital. There is no such inherent weakness in our government and there should not be on such a theory any sacrifice of the substantial property rights guaranteed by the constitution.

Without further consideration of mooted questions we note that the Adair case and the Hatter's case suggest:

Ist. That the boycott and sympathetic strike are agencies in business that cannot be employed without meeting the severe condemnation of courts; that the use of them is against common right and courts have the power to prevent or redress the wrong they inflict.

2nd. The decisions are a pronounced recognition of individualism. During the past twenty-five years there has been a mad rush for organization and the rights of the individual have been trampled upon and then conceded, only on condition that he become a member of some organization of capital or labor, and both of these factors have been equally at fault in this direction. The decisions plainly indicate that the constitutional guarantees are for the individual as against classes and organizations incorporated or unincorporated, that individualism is to have a reasonable opportunity and is not to be crushed out through the power of organization in the use of questionable means and measures, or through legislative limitations on freedom of action.

UNIVERSTYY OF MICHIGAN.

JEROME C. KNOWLTON, 